\title{
MITIGASI BENCANA PERKAWINAN ANAK SEBAGAI UPAYA MEWUJUDKAN KELUARGA SAKINAH: PERSPEKTIF FIKIH PERLINDUNGAN ANAK
}

\author{
Muhammad Habibi Miftakhul Marwa \\ Fakultas Hukum Universitas Ahmad Dahlan \\ email: habibi.marwa@law.uad.ac.id
}

disampaikan 14/10/2020 - di-review 19/04/2021 - diterima 20/11/2021

DOI: $10.25123 /$ vej.v7i2.4314

\begin{abstract}
Child marriage, in the final analysis, is denial of childrens basic right. The practice also violates the prevailing law which sets a statutory age limitation for both men and women to marry at 19 years. The author seeks to analyse this legal-societal issue from Islamic law perspective. The analysis starts from the general observation that to prevent future dissent-disolvement of marriages, both parties should consider "rusyd", in other words, their own or potential partners psychological, biological, and socio-economic maturity. In addition, to prevent child marriage, attention should be given to basic values of benefit (al mashlalah), the general principle of affection (mawaddah wa rahmah) and fulfillment of needs (taufir al-hajat).
\end{abstract}

Keywords: prevention; child marriage; fiqh.

\begin{abstract}
Abstrak
Perkawinan anak mengakibatkan hilangnya kesempatan anak-anak mendapatkan dan menikmati hak-hak dasar mereka. Padahal usia perkawinan dalam hukum negara telah ditetapkan bagi lakilaki dan perempuan adalah 19 tahun. Persoalan ini ditelaah dari sudut pandang hukum Islam. Titik tolak utama adalah bahwa untuk mencegah kemudaratan dalam perkawinan, pilihan calon pasangan seyogianya mempertimbangkan rusyd, kedewasaan psikologis, biologis, sosial-ekonomi. Terkait dengan ini adalah ikhtiar mencegah perkawinan anak berdasarkan nilai dasar kemaslahatan (al mashlalah), prinsip umum kasih sayang (mawaddah wa rahmah) dan pemenuhan kebutuhan (taufir al-hajat).
\end{abstract}

Kata Kunci: pencegahan; perkawinan anak; fikih.

\section{Pendahuluan}

Perkawinan anak merupakan praktik lama yang telah meluas di berbagai belahan dunia. Pola perkawinan anak dilakukan dengan menikahkan anak perempuan dengan laki-laki dewasa dan menjodohkan laki-laki dengan perempuan dimana salah satu atau keduanya dikategorikan masih berusia anakanak. $^{1}$ Badan Pusat Statistik (BPS) tahun 2017 menunjukkan bahwa angka perkawinan di bawah umur sebesar 25,2 persen atau 1 dari 4 anak perempuan

1 Reni Kartikawati and Djamilah, Dampak Perkawinan Anak Di Indonesia, 3.1, Jurnal Studi Pemuda, 1, 16, 2014. hlm. 3 
menikah pada usia anak (di bawah 18 tahun). Ada sekitar 340 ribu anak perempuan menikah sebelum umur 18 tahun. Sedangkan, tahun 2018 BPS mencatat sekitar 11,2 persen atau 1 dari 9 perempuan di Indonesia pada usia 20 sampai 24 tahun menikah sebelum usia 18 tahun. Berdasarkan statistik pemuda Indonesia BPS tahun 2018 menunjukkan bahwa 2 dari 100 pemuda melakukan perkawinan di bawah umur 16 tahun. Sekitar 20 provinsi dengan preferensi perkawinan anak di atas angka nasional tertinggi Provinsi Sulawesi Barat yaitu 19,4 persen, sementara terendah adalah Provinsi DKI Jakarta, 4,1 persen. Kondisi demikian apabila tidak segera dicarikan penyelesaian, Indonesia akan mengalami darurat perkawinan anak yang berakibat tidak terpenuhinya hak-hak anak sebagaimana amanat konstitusi ${ }^{2}$ dan bertentangan dengan prinsip-prinsip perlindungan anak seperti prinsip tumbuh kembang anak serta prinsip yang terbaik untuk anak. ${ }^{3}$ Menurut Hasto Wardoyo, Kepala Kependudukan dan Keluarga Berencana Nasional (BKKBN), menyebutkan bahwa perkawinan usia dini dapat dikategorikan sebagai bagian bencana nasional karena dapat menggerogoti ekonomi negara dan berdampak pada kebutuhan dasar anak yang tidak terpenuhi. ${ }^{4}$

Penyebab terjadinya perkawinan anak selain karena hamil di luar nikah, kemiskinan, minimnya pendidikan, agama, dan budaya, serta besarnya toleransi yang diberikan Undang-Undang Nomor 1 Tahun 1974 tentang Perkawinan yang kemudian diubah dengan Undang-Undang Nomor 16 Tahun 2019 tentang Perubahan Atas Undang-Undang Nomor 1 Tahun 1974 tentang Perkawinan (disingkat Undang-Undang Perkawinan). Undang-Undang Perkawinan yang lama menyatakan seseorang diizinkan melakukan perkawinan jika laki-laki sudah berusia 19 tahun dan perempuan usia 16 tahun. Ketentuan umur 16 tahun bagi perempuan dianggap tidak mencerminkan perlindungan anak. Apalagi adanya

2 Dewan Pimpinan Republik Indonesia Rakyat, Risalah Dalam Rangka Penyusunan RUU Tentang Perubahan UU Perkawinan, DPR Republik Indonesia, Jakarta, 2019, hlm. 5

3 Fadli Andi Natsif, Problematika Perkawinan Anak Perspektif Hukum Islam Dan Hukum Positif, 5.2, Jurnal Al-Qadau: Peradilan Dan Hukum Keluarga Islam, 175, 186, 2018, hlm. 184

4 Badan Kependudukan dan Keluarga Berencana (BKKBN) https://www.bkkbn.go.id/detailpost/perkawinan-usia-anak-bencana-nasional-yang-gerogotiekonomi-indonesia, diakses pada 30 April 2021, jam 10.14 WIB. 
pengaturan dispensasi nikah menjadi celah terjadinya perkawinan anak. Ada batasan yang harus diperhatikan saat memberikan dispensasi nikah yaitu adanya alasan sangat mendesak, biasanya karena terlanjur hamil di luar nikah. ${ }^{5}$ Problem yang belum terpecahkan yaitu perkawinan di bawah umur digolongkan melanggar hukum, namun sanksi hukumannya tidak diatur secara tegas dalam undangundang tersebut. ${ }^{6}$

Membangun keluarga sakinah harus dirancang sejak melakukan pemilihan pasangan dengan mempertimbangkan aspek kedewasaan biologis dan psikologisosial. Kedewasaan harus dipahami bukan hanya dari sisi usia tetapi juga kesiapan calon pengantin sebelum berumah tangga. Pengaturan usia minimal dalam Undang-Undang Perkawinan sebelum perubahan lebih dominan aspek kedewasaan biologis. ${ }^{7}$ Seiring disosialisasikan Undang-Undang Nomor 23 Tahun 2002 tentang Perlindungan Anak maupun Undang-Undang Nomor 35 Tahun 2014 tentang Perubahan Undang-Undang Nomor 23 Tahun 2002 tentang Perlindungan Anak (disingkat Undang-Undang Perlindungan Anak), disebut anak bagi yang berusia di bawah 18 tahun. Maka usia minimal dalam Undang-Undang Perkawinan lama dikategorikan usia di bawah umur sehingga menimbulkan silang pendapat di kalangan masyarakat sampai ada yang mengajukan judicial review ke Mahkamah Konstitusi. Hingga akhirnya Senin, 16 September 2019, Dewan Perwakilan Rakyat mengesahkan Undang-Undang Perkawinan yang baru sebagai momentum untuk mencegah pernikahan dini dimana perkawinan hanya diizinkan apabila pria dan wanita sudah mencapai umur 19 tahun.

Perkawinan anak menghambat tercapainya hak-hak anak yang seharusnya dilindungi. Hak anak merupakan hak asasi manusia yang wajib dijamin, dilindungi,

5 Thogu Ahmad Siregar and Petrus Richard Sianturi, Dispensasi Kawin Akibat Hamil Di Luar Perkawinan Dan Dampaknya Pada Formulasi Pidana Zina, 6.2. Veritas et Justitia, 424, 449, 2020, hlm. 446

6 Sofia Hardani, Analisis Tentang Batas Umur Untuk Melangsungkan Perkawinan Menurut Perundang-Undangan Di Indonesia, 40.2 An-Nida': Jurnal Pemikiran Islam, 126, 139, 2015, hlm. 138

7 Inna Noor Inayati, Perkawinan Anak Di Bawah Umur Dalam Perspektif Hukum, HAM Dan Kesehatan, 1.1, Jurnal Bidan: Midwife Journal, 46, 53, 2015, hlm. 1 
dan dipenuhi oleh orang tua, keluarga, masyarakat, dan negara. ${ }^{8}$ Selain itu, setiap anak juga berhak atas kelangsungan hidup, tumbuh berkembang, mempertahankan hidup, meningkatkan taraf kehidupannya ${ }^{9}$, dan berhak memperoleh pelayanan kesehatan dan jaminan sosial secara layak sesuai dengan kebutuhan fisik dan mental spiritualnya. ${ }^{10}$ Maraknya pernikahan diri menjadikan hak-hak anak sulit tercapai.

Muhammadiyah salah satu yang merespon persoalan anak. Melalui Majelis Tarjih dan Tajdid Pimpinan Pusat Muhammadiyah telah menyelenggarakan Musyawarah Nasional Tarjih Muhammadiyah XXX Tahun 2018 di Makassar dengan salah satu bahasan mengenai Fikih Perlindungan Anak. Fikih ini disusun untuk dijadikan tuntunan dan rujukan dalam menyikapi berbagai permasalahan anak perspektif hukum Islam. Selain itu, fikih ini memiliki relevansi terhadap fenomena pernikahan anak di Indonesia yang sangat mengkhawatirkan hingga akhirnya pemerintah menetapkan batas minimal usia perkawinan laki-laki dan perempuan adalah 19 tahun.

Berdasarkan penjelasan di atas penulis tertarik mengambil rumusan masalah, bagaimana konsep kedewasaan dan mitigasi perkawinan anak perspektif fikih perlindungan anak sebagai upaya untuk mewujudkan keluarga sakinah? Artikel ini merupakan penelitian hukum normatif dengan menggunakan sumber data sekunder. Metode pengumpulan data sekunder diperoleh melalui studi pustaka untuk mendapatkan data hukum primer, sekunder, dan tersier. Untuk melengkapi data sekunder dilakukan wawancara dengan Majelis Tarjih dan Tajdid Muhammadiyah. Dari data yang diperoleh kemudian diklasifikasikan dan

8 Undang-Undang R.I. No. 23 Tahun 2002, Perlindungan Anak, L.N.R.I. Tahun 2002 No. 109, Pasal 1 angka (15)

9 Undang-Undang Dasar Negara R.I Tahun 1945, Pasal 28B ayat (2), jo. Undang-Undang R.I No.39 Tahun 1999, Hak Asasi Manusia, L.N.R.I. Tahun 1999 No. 165, Pasal 53 ayat (1)

10 Undang-Undang R.I. No.39 Tahun 1999, Hak Asasi Manusia, L.N.R.I. Tahun 1999 No. 165, Pasal 62, jo Undang-Undang R.I. No. 23 Tahun 2002, Perlindungan Anak, L.N.R.I. Tahun 2002 No. 109 , Pasal 8 
disistematisasi untuk dianalisis secara deskriptif dengan pendekatan konsep (conceptual approach) yaitu fikih perlindungan anak. ${ }^{11}$

\section{Pembahasan}

\section{Konsep Kedewasaan}

Pasal 1 Undang-Undang Perkawinan menjelaskan bahwa:

"Perkawinan adalah ikatan lahir batin antara seorang pria dengan seorang wanita sebagai suami istri dengan tujuan membentuk keluarga atau rumah tangga yang bahagia dan kekal berdasarkan Ketuhanan Yang Maha Esa."

Guna mewujudkan tujuan perkawinan yang bahagia dan kekal harus dipertimbangkan dengan baik dalam memilih pasangan hidup adalah masalah kedewasaan. Kedewasaan dalam perkawinan menjadi hal penting yang mempengaruhi keberhasilan rumah tangga. Kesiapan dan kematangan calon pengantin sebagai prasyarat membangun rumah tangga yang bahagia, memperoleh keturunan yang baik dan sehat, dan kekal tidak berakhir perceraian. $^{12}$

Hukum Islam tidak mengatur secara tegas tentang batas usia minimal untuk menikah melalui umur, melainkan menggunakan ukuran baligh dan mukallaf. Tidak diaturnya usia perkawinan dalam rukun dan syarat perkawinan untuk memberikan kemudahan bagi manusia dalam mengaturnya. ${ }^{13}$ Artinya, batas minimal usia nikah merupakan persoalan fikih yang terikat oleh situasi masyarakat dimana fikih tersebut diberlakukan. Hal ini menunjukkan bahwa masalah usia perkawinan diserahkan kepada manusia untuk menentukan berdasarkan kondisi dan perkembangan zaman masing-masing. Nabi Muhammad saw. bersabda sebagaimana yang diriwayatkankan oleh Imam Bukhari:

"Wahai para pemuda, barang siapa yang telah mampu (istita'ah), maka menikahlah. Sebab, menikah itu lebih menundukkan pandangan dan

11 Mukti Fajar Nur Dewata and Yulianto Achmad, Dualisme Penelitian Hukum Normatif \& Empiris, I, Pustaka Pelajar, Yogyakarta, 2010, hlm. 158

12 Aprianti, Zahroh Shaluhiyah, and Antono Suryoputro, Fenomena Pernikahan Dini Membuat Orang Tua Dan Remaja Tidak Takut Mengalami Kehamilan Tidak Diinginkan, 13.1, Jurnal Promosi Kesehatan Indonesia, 61, 73, 2018, hlm. 62

13 M Ghufron, Makna Kedewasaan Dalam Perkawinan, 06. 02, Al-Hukama': The Indonesia Journal of Islamic Family Law, 319, 336, 2016, hlm. 321 
menjaga kehormatan diri. Barangsaiapa yang tidak mampu, maka hendaklah ia berpuasa. Karena sesungguhnya puasa itu dapat meredam nafsunya" (HR. Bukhari). ${ }^{14}$

Berdasarkan hadist di atas dapat dipahami bahwa istita'ah menjadi prasyarat pernikahan untuk mewujudkan tujuan perkawinan. Kemampuan atau kesanggupan merupakan bagian dari kedewasaan seseorang secara fisik, mental, dan finansial yang belum tentu dimiliki oleh anak yang masih di bawah umur. Sehingga bagi yang belum dewasa harus menunda perkawinanya sampai sudah dinyatakan dewasa dan mampu secara fisik, mental, dan ekonomi.

Ada tiga istilah mengenai konsep kedewasaan dalam Al-Qur'an, yaitu baligh (QS. An-Nur: 59), rusyd (QS. An-Nisa': 6), dan asyuddah (QS. Al-Ahqaf: 15) dan (AlQashash: 14). ${ }^{15}$ Baligh merupakan fase dimana seseorang mengalami kedewasaan secara fisik (biologis) dengan ciri mengalami mimpi basah (laki-laki) dan menstruasi (perempuan). Hal ini ditegaskan dalam firman Allah Swt.:

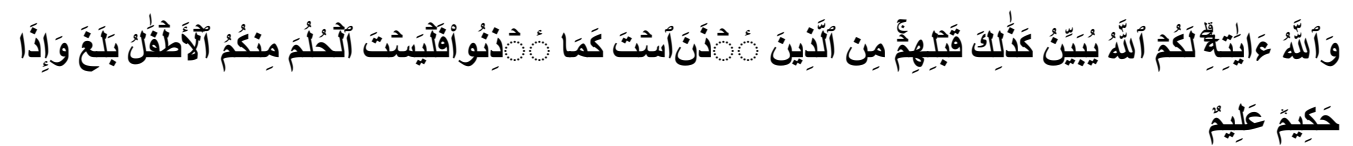

"Dan apabila anak-anakmu telah sampai umur baligh, maka hendaklah mereka meminta izin, seperti orang-orang yang sebelum mereka meminta izin. Demikianlah Allah menjelaskan ayat-ayat-Nya. Dan Allah Maha Mengetahui lagi Maha Bijaksana." (QS. An-Nur: 59)

Jika tanda-tanda fisik baligh tidak muncul pada waktunya, maka kedewasaan ditandai dengan usia. Anak yang belum baligh dengan tanda-tanda fisik disebut anak mumayyiz yaitu anak semenjak usia tujuh tahun hingga dewasa, seperti sabda Nabi Muhammad saw.: "Suruhlah anak-anakmu shalat ketika mereka berusia tujuh tahun, dan hukumlah mereka apabila setelah berusia sepuluh tahun belum juga shalat." (HR. Abu Dawud). ${ }^{16}$

\footnotetext{
14 Abu 'Abdillah Muhammad Ibn Ismail Bukhari, ed. by Mustafa Dib Al-Buga, Sahih Bukhari, Dar Ibn Kasir dan Al-Yamamah li At-Tiba'ah wa An-Nasyr wa Ta-Tauzi, Damaskus, 1994.

15 Wawancara dengan Hamim Ilyas, Wakil Ketua Majelis Tarjih dan Tajdid Pimpinan Pusat Muhammadiyah, tanggal 26 Juni 2020 jam 14.08 WIB

16 Abu Dawud Sulaiman Ibn Al- Asy's As-Sinistani, ed. by Syu'aib Al-Arna'ut dan Muhammad Kamil Qarah Balali, Sunan Abi Dawud, Mu'assasat Ar-Risalah li At-Tiba'ah wa An-Nasyr wa AtTauzi, Beirut, 1994.
} 
Kesiapan menikah minimal harus mempertimbangkan rusyd bukan baligh. Rusyd merupakan fase seseorang mampu mengatur hidupnya sendiri termasuk dalam mengasuh anak. Rusyd mengandung kesempurnaan akal dan jiwa yang menjadikan seseorang memiliki kemampuan untuk bersikap dan bertindak setepat mungkin. Jika baligh lebih ditekankan pada aspek fisik, maka rusyd ukuran kedewasaan dalam aspek psikologi-sosial, sehingga memiliki kecakapan dan kepandaian dalam mengatur hidupnya. Membangun keluarga sakinah tidak cukup hanya berpegang pada fisiologis saja, tetapi harus pakai standar rusyd. ${ }^{17}$ Pentingnya memperhatikan rusyd bagi calon pasangan pengantin dinyatakan dalam firman Allah Swt:

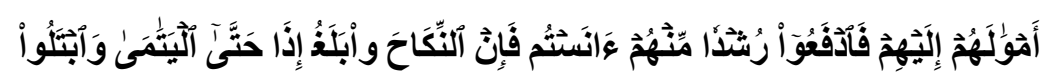

"Dan ujilah anak yatim itu sampai mereka cukup umur untuk kawin. Kemudian jika menurut pandapatmu mereka telah cerdas (pandai memelihara harta), maka serahkanlah kepada mereka harta-hartanya..." (Q.S. An-Nisa: 6)

Ayat di atas memuat dua tanda kedewasaan, yaitu mencapai usia mampu untuk menikah, dan rusyd (cerdas memelihara harta). Ditekankannya kedewasaan seseorang dalam melakukan perkawinan dalam rangka mewujudkan kemaslahatan dan mencegah kemudharatan (hal-hal merugikan). Mampu menikah yang dimaksud adalah kemampuan organ seksual dalam menjalankan fungsinya sebagai orang dewasa secara biologis dengan ciri-ciri telah ihtilam atau mimpi basah atau menstruasi. Sedangkan rusyd, yaitu dewasa atau matang secara psikologis dan sosial. Mampu melangsungkan perkawinan tidak cukup hanya baligh saja, melainkan harus ditambah syarat kedua yaitu rusyd.

Adanya batas usia anak merupakan batas maksimum untuk menunjukkan kemampuan seseorang dan dinyatakan mulai memiliki status di hadapan hukum. Hal ini berakibat beralihnya status usia anak menjadi usia dewasa yang dapat bertanggung jawab secara mandiri atas perbuatan hukum yang dilakukan. Ketentuan kedewasaan di dalam Islam jika dianalisis menggunakan peraturan

17 Muhammad Habibi Miftakhul Marwa, Pengaturan Batas Usia Perkawinan Perspektif Keluarga Sakinah Muhammadiyah, 7.1, Justisi, 1, 13, 2021, hlm. 10 
perundang-undangan akan ditemukan perbedaan dalam penentuan batas anak dan dewasa. Pasal 330 Kitab Undang-Undang Hukum Perdata (KUH Perdata) menyatakan anak adalah seseorang yang belum mencapai usia 21 tahun, kecuali kalau sudah menikah. Seseorang yang telah menikah meskipun belum berusia 21 tahun tidak akan menjadi belum dewasa lagi jika pernikahan tersebut bubar. Pengaturan ini menunjukkan kalau KUH Perdata memandang kematangan seseorang jika telah berusia 21 tahun dimana secara biologis dan psikologis dianggap mampu dan cakap melakukan perbuatan keperdataan. Undang-Undang Nomor 4 Tahun 1979 tentang Kesejahteraan Anak menegaskan bahwa disebut anak bagi yang belum berusia 21 tahun dan belum pernah kawin. Begitu juga Pasal 98 ayat (1) Kompilasi Hukum Islam (KHI) menggunakan batas usia anak yang mampu berdiri sendiri atau dewasa adalah 21 tahun, sepanjang anak tersebut tidak cacat fisik maupun mental atau belum pernah melangsungkan perkawinan. Dari berbagai peraturan tersebut dapat dipahami kalau usia dewasa seseorang ketika sudah berusia 21 tahun atau sudah kawin, tidak catat atau gila, dan dapat bertanggung jawab atas dirinya.

Undang-Undang Nomor 3 Tahun 1997 tentang Peradilan Anak, UndangUndang Nomor 39 Tahun 1999 tentang Hak Asasi Manusia, dan Undang-Undang Nomor 13 Tahun 2003 tentang Ketenagakerjaan, dan Undang-Undang Perlindungan Anak mendefinisikan anak adalah orang yang belum mencapai umur 18 tahun. Anak dalam pandangan Muhammadiyah adalah seseorang yang belum berumur 18 tahun untuk urusan muamalah dan 12 tahun untuk urusan ibadah. Artinya, seseorang dikatakan dewasa jika sudah berusia di atas 18 tahun. UndangUndang Perkawinan terbaru menggunakan usia dewasa laki-laki dan perempuan adalah 19 tahun. Usia dewasa 19 tahun menurut penulis telah memenuhi kriteria kematangan umur seseorang untuk melangsungkan perkawinan dimana sudah terjadi akumulasi kesiapan secara fisik (biologis), ekonomi, sosial, dan psikologi (kejiwaan). Setidaknya umur segitu telah mengacu pada aspek kesehatan dan kondisi anak yang kelak akan dilahirkan.

Sedangkan, asyuddah merupakan kedewasaan yang sempurna dari segi fisik, ilmu pengetahuan, dan sosial-ekonomi. Ibarat buah, maka fase baligh itu 
masih mentah, fase rusyd sudah masak, dan fase asyuddah sudah matang. Fase asyuddah dinyatakan dalam Al-Qur'an sebagai berikut:

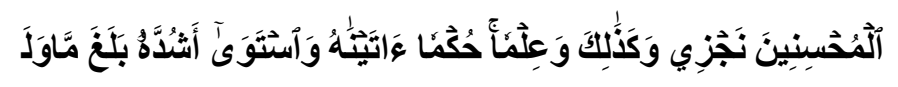

"Dan setelah Musa cukup umur dan sempurna akalnya, Kami berikan kepadanya hikmah (kenabian) dan pengetahuan. Dan demikianlah Kami memberi balasan kepada orang-orang yang berbuat baik." (QS. Al-Qasas: 14)

Menurut Tafsir Jalalain, yang dimaksud baligh sehingga layak melangsungkan perkawinan adalah sudah mimpi basah atau menstruasi. Jika memakai ukuran Imam Syafii, usia baligh seseorang 15 tahun. Rusyd menggunakan parameter kepatutan dalam bidang agama dan harta benda, sementara asyuddah yaitu dewasa karena telah mencapai kesempurnaan kekuatan (fisik), akal, dan pemikirannya dengan minimal usia 30 tahun atau 33 tahun, dan puncak kesempurnaan akalnya di usia 40 tahun. Usia dewasa (asyuddah) yang dijelaskan dalam surat Al-Ahqaf ayat 15 adalah setelah seorang anak dikandung dan disapih oleh ibunya hingga tiga puluh bulan hingga telah mencapai umur 40 tahun. Ayat ini turun ketika Abu Bakar Ash-Shidiq berusia 40 tahun, yaitu dua tahun setelah diutusnya Nabi Muhammad sebagai rasul. ${ }^{18}$

Menurut Imam Hanifah, kedewasaan seseorang mulai 18 tahun bagi lakilaki dan 17 tahun untuk perempuan. Adapun kedewasaan menurut Imam Malik, menetapkan 18 tahun baik laki-laki maupun perempuan. Sedangkan, Imam Syafii dan Hanbali, menentukan masa kedewasaan seseorang ditandai mimpi basah atau menstruasi, tetapi karena tanda-tanda itu datangnya tidak sama pada semua orang, maka kedewasaan ditentukan dengan umur. Disamakannya masa kedewasaan antara laki-laki dan perempuan karena kedewasaan itu ditentukan dengan akal, dengan akal akan timbul taklif, dan karena akal juga hukum menjadi ada. ${ }^{19}$ Imam Ja'fari berpendapat bahwa wali dapat mengawinkan anaknya

18 Al-Imam Jalaluddin Muhammad bin Ahmad bin Muhammad Al-Mahalli and Al-Imam Jalaluddin Abdirrahim bin Abu Bakar As-Suyuthi, Tafsir Jalalain, eLBA, Surabaya, 2012, hlm. 776

19 Mardi Candra, Aspek Hukum Perlindungan Anak Di Indonesia : Analisis Tentang Perkawinan Di Bawah Umur, 1st edn, Prenadamedia Group, Jakarta, 2018, hlm. 50 
meskipun baru berusia 15 tahun bagi laki-laki dan 9 tahun bagi perempuan. ${ }^{20}$ Mengingat menikah di bawah umur mengandung madharat, sedangkan Islam melarang kemudharatan, maka usia ideal perkawinan adalah 21 tahun dengan tidak membedakan laki-laki dan perempuan dengan merujuk Ali bin Abi Thalib yang membagi tiga fase dalam mendidik anak, di mana masing-masing fase adalah 7 tahun. $^{21}$

Tingkat kecakapan seseorang sudah ada sejak dalam kandungan hingga akhir hayat. Periode janin dimulai sejak dalam kandungan sampai lahir. Periode anak dimulai saat lahir hingga usia tujuh tahun. Periode mumayyiz saat usia tujuh tahun hingga dewasa. Periode dewasa berlangsung hingga meninggal dunia. ${ }^{22}$ Khasanah ushul fiqh telah mengenalkan dua macam kecakapan seseorang, yaitu (1) ahliyah al-wujub yaitu kecakapan menerima hak dan kewajiban, (2) ahliyah al$a d a^{\prime}$ yaitu kecakapan menjalankan hukum. Ahliyah al-ada' dibagi tiga macam yaitu: (1) 'Adim al-Ahliyyah yaitu sama sekali tidak cakap, seperti seorang anak yang masih kecil dan belum baligh; (2) Ahliyyah al-Ada' Naqișah yaitu sudah mempunyai kecakapan namun belum sempurna; dan (3) Ahliyyah al-Ada' Kamilah yaitu sudah kecakapan yang sempurna. Dengan melihat konsep kecakapan dalam ushul fiqh di atas, maka perkawinan di bawah umur masuk tingkatan kedua yaitu belum memiliki kecakapan sempurna (Ahliyyah al-Ada' Naqișah). Apabila pasangan suami-isteri belum kecakapan secara sempurna, maka akan kesulitan mewujudkan rumah tangga yang sakinah, mawaddah, wa rahmah. ${ }^{23}$

Fakta lain ada sebagian masyarakat muslim masih menikahkan anaknya yang belum dewasa dengan sebab tertentu diantaranya karena tradisi dan agama. Misalnya di Pakistan, Afganistan, dan sejumlah negara Timur Negara, dimana

20 Nur Fadhilah Khairiyati Rahmah, Rekontruksi Batas Usia Perkawinan Anak Dalam Hukum Nasional Indonesia, 4.1, Journal de Jure, 49, 61, 2012, hlm. 52

21 Hasil wawancara dengan Wawan Gunawan Abdul Wahid, Anggota Majelis Tarjih dan Tajdid Pimpinan Pusat Muhammadiyah tanggal 24 Januari 2020 jam 18. 12 WIB

22 Majelis Tarjih dan Tajdid Pimpinan Pusat Muhammadiyah, Materi Musyawarah Nasional Tarjih Muhammadiyah XXX, I, Panitia Muasyawarah Nasional Tarjih Muhammadiyah XXX, Yogyakarta, 2018, hlm. 14

23 Muhammad Fuad Zain and Ansori Ansori, Rekontruksi Batas Usia Perkawinan Pasca Putusan MK No. 22/PUU-Xv/2017 Sebagai Penguat Bangsa Di Era Industri 4.0, 1.1, ADHKI: Journal of Islamic Family Law, 45, 56, 2019, hlm. 53 
orang tua menikahkan anak perempuannya dengan motif untuk membantu keluarga mempelai laki-laki membayar hutang atau bahkan menyelesaikan perselisihan keluarga. ${ }^{24}$ Dalil agama yang sering digunakan adalah hadist Nabi Muhammad saw.: "Nabi saw. menikahi Aisyah ketika berumur 6 tahun dan mulai hidup bersama ketika usianya 9 tahun." (HR. Bukhari). ${ }^{25}$

Hadist di atas hanya memberi kabar (khabariyah) mengenai perkawinan Nabi Muhammad saw., tidak menyatakan perintah maupun larangan soal perkawinan di bawah umur, sehingga tidak dapat disimpulkan sebagai pernyataan adanya batas minimal usia dibolehkannya perkawinan bagi perempuan. ${ }^{26}$ Ibnu Syubromah dalam memahami hadits tersebut tidak secara tekstual, namun melihat dari aspek historis, sosiologis, dan kultural saat itu. ${ }^{27}$ Sekalipun hadis tersebut hendak dijadikan rujukan, maka harus dipahami bahwa kebolehan tersebut sifatnya khusus (lex spesialis) bukan kebolehan secara umum (lex generalis). Artinya, perkawinan Nabi Muhammad saw. dengan Aisyah merupakan ketentuan yang sifatnya khusus bagi Rasulullah yang tidak dapat begitu saja dilakukan oleh umatnya. ${ }^{28}$ Abu Yusuf, murid Abu Hanifah, juga menyatakan bahwa praktik perkawinan Aisyah usia 6 tahun dan baru berkumpul dengan Nabi Muhammad di usia 9 tahun dapat dibenarkan untuk kondisi saat itu, namun konteks sekarang apalagi sudah ada aturan pemerintah yang membatasi usia perkawinan adalah 19 tahun, maka perkawinan di bawah usia itu tidak diajurkan. $^{29}$

Sebagian orientalis yang membenci Islam dan umat Islam menggunakan hadist perkawinan Nabi Muhammad dengan Aisyah untuk menyerang pribadi Rasulullah dengan menuduh sebagai sosok yang suka menikah dengan perempuan

\footnotetext{
24 Sonny Dewi Judiasih, et al, Perkawinan Bawah Umur Di Indonesia : Beserta Perbandingan Usia Perkawinan Dan Praktik Perkawinan Bawah Umur Di Beberapa Negara, Kesatu, PT. Refika Aditama, Bandung, 2018, hlm. 26

25 Pimpinan Pusat 'Aisyiyah and Majelis Tarjih dan Tajdid Pimpinan Pusat Muhammadiyah, Tuntunan Menuju Keluarga Sakinah, II, Suara Muhammadiyah, Yogyakarta, 2017, hlm. 64

26 Supri Yadin Hasibuan, Pembaharuan Hukum Perkawinan Tentang Batas Minimal Usia Pernikahan Dan Konsekuensinya, 1.2, Teraju : Jurnal Syariah Dan Hukum, 79, 87, 2019, hlm. 5

27 Hardani, supra no. 6, hlm. 137

28 Khairiyati Rahmah, supra no. 20, hlm. 53

29 Natsif, supra no 3, hlm. 181
} 
di bawah umur. Tuduhan semacam ini harus diluruskan dengan cara memahami hadist tersebut secara komprehensif. Aisyah dipersunting Rasulullah berdasarkan perintah Allah melalui wahyu dalam mimpi beliau ${ }^{30}$, sebagaimana sabda Nabi Muhammad saw.:

"Aku melihatmu dalam mimpiku selama tiga malam, ketika itu datang bersamamu malaikat yang berkata: ini adalah istrimu. Lalu aku singkap tirai yang menyembunyikan wajahmu, lalu aku berkata sesungguhnya hal itu telah ditetapkan di sisi Allah." (HR. Bukhari Muslim). ${ }^{31}$

Hadist pernikahan Aisyah dengan Nabi Muhammad saw., harus diposisikan dan dipahami dengan benar melalui tiga tinjauan. Pertama, tinjauan perawi. Riwayat yang menyebutkan usia perkawinan Aisyah dengan Rasulullah ini hanya berasal dari Hisyam bin 'Urwah, tidak oleh Abu Hurairah atau Anas bin Malik. Usia Hisyam waktu itu sudah 71 tahun dan telah berpindah ke Irak saat meriwayatkan hadist tersebut. Menurut para ahli, saat Hisyam sudah berusia lanjut ingatannya sangat menurun. Oleh karena hanya Hisyam sendiri yang meriwatkan, maka layak dikritisi. Ya'kub bin Syaibah, dalam penilaiannya menyebutkan: “Apa yang diriwayatkan Hisyam sangat terpercaya, kecuali yang diceritakannya saat ia telah menetap di Irak." Ya'kub juga menambahkan jika Anas bin Malik menolak informasi Hisyam terkait usia perkawinan Rasulullah dengan Aisyah ini. ${ }^{32}$

Kedua, tinjauan historis. Menurut at-Thabari, empat anak Abu Bakar AsSidiq, termasuk Aisyah dilahirkan pada masa jahiliyah sebelum tahun $610 \mathrm{M}$. Jika Aisyah dinikahkan saat usia 6 tahun, maka ia lahir pada tahun $613 \mathrm{M}$. Hal ini tentu bertentangan dengan keterangan at-Thabari di atas yang menyebutkan kelahiran Aisyah sebelum tahun 610 M. Berikutnya, jika Aisyah dinikahkan sebelum tahun $620 \mathrm{M}$, berarti Aisyah tidak mungkin menikah di bawah umur 10 tahun dan dengan demikian seharusnya hidup bersama dengan Nabi pada usia di atas 13 tahun. Selain itu, untuk mengetahui usia tepat Aisyah menikah dengan Nabi dapat dibandingkan dengan usia kakak perempuan Aisyah yaitu Asma' binti Abu Bakar.

30 Muhammad Syafii Antonio, Muhammad SAW.: The Super Leader Super Manager, IX, Tazkia Multimedia \& ProLM Center, Jakarta, 2009, hlm. 302

31 Muslim, Shahih Muslim, ed. by Muhammad Fuad Abd Baqi, Dar Al-Fikr li At-Tiba'ah wa AnNasyr wa At-Tauzi, Beirut, 1994.

32 Muhammadiyah, supra no. 22, hlm. 78 
Menurut Abdurrahman bin Abi Zinad, usia Aisyah dengan Asma selisih 10 tahun. Menurut Ibnu Hajar Al-Asqalani, Asma hidup hingga usia 100 tahun dan meninggal dunia pada tahun 73 atau $74 \mathrm{H}$. Artinya, apabila Asma' meninggal dalam usia 100 tahun dan meninggal dalam tahun 73 atau $74 \mathrm{H}$, berarti, saat peristiwa hijrah terjadi usia Asma' sekitar 27 atau 28 tahun (100-73). Sehingga usia Aisyah (27 atau 28) - 10 sama dengan 17 atau 18 tahun waktu hijrah. Dengan demikian, usia Aisyah saat menikah dengan Rasulullah adalah antara 17 tahun atau 18 tahun (usia Asma 27 atau 28 tahun - 10 tahun usia Aisyah). ${ }^{33}$

Ketiga, tinjauan hukum Islam. Pernikahan Aisyah dengan Nabi Muhammad saw. terjadi saat periode Makkah. Ayat-ayat yang turun pada periode Makkah (Makkiyah) berkaitan dengan akidah dan akhlak. Periode tersebut belum memasuki masa tasyri' yaitu masa dirumuskannya hukum-hukum far'iyyah 'amaliyyah. Oleh karena itu, hadist yang menjelaskan peristiwa perkawinan Aisyah dengan Rasulullah di mana usia Aisyah masih 6 tahun dan hidup bersama Nabi pada usia 9 tahun, tidak dapat dijadikan pijakan terhadap penetapan perkawinan anak. $^{34}$

Kedewasaan seseorang merupakan salah satu pertimbangan untuk memberikan perlindungan terhadap anak. Hal ini dikarenakan dalam perkawinan terdapat tanggung jawab yang akan diemban pasangan pengantin baik sebagai suami-istri maupun orang tua bagi anak-anaknya kelak. Kedewasaan menjadi salah satu indikator penting dalam penentuan kebahagiaan keluarga, dimana hal tersebut menuntut adanya kesiapan suami-istri secara psikologi, sosial, dan ekonomi dalam membangun rumah tangga. Karena, sejatinya spirit pernikawinan Islam adalah untuk menjaga kemaslahatan keluarga dengan kemampuan menjalankan fungsi-fungsi keluarga, seperti fungsi spiritual, sosial, finansial, dan pendidikan. Pasangan yang belum memiliki kedewasaan yang cukup dianggap sulit mewujudkan fungsi keluarga yang seharusnya dikerjakan bersama antara suami-istri dalam rumah tangga. Pentingnya kedewasaan bagi calon pengantin dalam perkawinan guna mempersiapkan mental yang matang untuk membina

33 'Aisyiyah and Muhammadiyah'Aisyiyah and Muhammadiyah. supra no. 25, hlm. 66, 67

34 Id, hlm. 79 
keluarga yang bahagia. Pasangan yang belum mencapai usia dewasa akan kesulitan melaksanakan tujuan perkawinan. Seseorang yang telah memberanikan diri membentuk rumah tangga berarti harus berani pula mencukupi kebutuhan keluarga dan anak-anaknya. Bagi yang belum memiliki kesiapan mental dan finansial justru akan menimbulkan persoalan di kemudian hari yang berdampak terhadap keretakan keluarga.

\section{Fikih Perlindungan Anak}

Indonesia memiliki perhatian relatif lebih maju dalam bidang hukum perlindungan anak karena diatur dalam Undang-Undang Dasar Negara Republik Indonesia Tahun 1945 (disingkat UUD NRI 1945) dan Undang-Undang Perlindungan Anak. Perlindungan anak didefinisikan sebagai:

"Segala bentuk kegiatan untuk menjamin dan melindungi anak dan hakhaknya supaya dapat hidup, tumbuh, berkembang, dan berpartisipasi secara optimal sesuai harkat dan martabatnya, serta mendapat perlindungan dari segala macam kekerasan dan diskriminasi." ${ }^{35}$

Perlindungan dapat dimaknai sebagai kegiatan langsung maupun tidak langsung untuk menghindarkan anak dari tindakan yang membahayakan fisik dan/atau psikis. ${ }^{36}$ Artinya, dalam setiap fase kehidupan anak harus mendapat perlindungan yang berkelanjutan dan terarah untuk menjamin hak dasar anak supaya fisik dan mentalnya dapat tumbuh dan berkembang secara baik. ${ }^{37}$ Intinya perlindungan anak adalah terpenuhinya hak-hak asasi anak yang melekat sejak dilahirkan sampai meninggal dunia, seperti perlindungan terhadap agama, kesehatan pendidikan, hak sosial, dan perlindungan yang sifatnya khusus.

Perlindungan terhadap hak-hak anak dinyatakan dalam Pasal 28B UUD NRI 1945. Tujuan perlindungan anak adalah untuk menjamin terpenuhinya hak-hak dasar anak supaya dapat melangsungkann hidup, berkembang, dan berpartisipasi

\footnotetext{
35 Undang-Undang R.I. No. 23 Tahun 2002, Perlindungan Anak, L.N.R.I. Tahun 2002 No. 109, Pasal 1 ayat (1)

36 Analiansyah and Syarifah Rahmatillah, Perlindungan Terhadap Anak Yang Berhadapan Dengan Hukum: Studi Terhadap Undang-Undang Peradilan Anak Indonesia Dan Peradilan Adat Aceh, 1.1, Gender Equality: Internasional Journal Of Child And Gender Studies, 51, 68, 2015, hlm.5

37 Fransiska Novita Eleanora and Andang Sari, Pernikahan Anak Usia Dini Ditinjau Dari Perspektif Perlindungan Anak, XIV.1, Progresif : Jurnal Hukum, 50, 63, 2020, hlm. 58
} 
secara optimal sesuai dengan harkat dan martabat kemanusiaan, serta memperoleh perlindungan dari setiap tindakan kekerasan dan diskriminasi dalam rangka terwujudnya anak Indonesia yang berkualitas tinggi, berakhlak mulia, dan hidup sejahtera.

Islam telah memberikan petunjuk penting terhadap perlindungan anak seperti hak untuk hidup, dan tumbuh dan berkembang. Sebagaimana dalam firman Allah Swt:

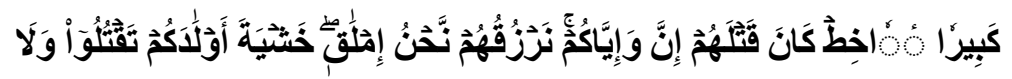

"Dan janganlah kamu membunuh anak-anakmu karena takut kemiskinan. Kamilah yang akan memberi rezeki kepada mereka dan juga kepadamu. Sesungguhnya membunuh mereka adalah suatu dosa yang besar." (QS. AlIsra': 31).

Anak juga harus mendapat perlindungan dari kekerasan dan diskriminasi, perlakuan adil, hak memperoleh nama, status, dan mengetahui orang tuanya, seperti dijelaskan dalam firman Allah Swt:

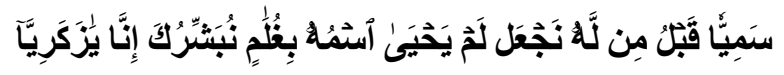

"Hai Zakaria, sesungguhnya Kami memberi kabar gembira kepadamu akan (beroleh) seorang anak yang namanya Yahya, yang sebelumnya Kami belum pernah menciptakan orang yang serupa dengan dia." (QS. Maryam : 7)

Fikih perlindungan anak merupakan kelanjutan dari pembahasan mengenai tuntunan penguatan dan pemberdayaan anak yang sudah disahkan menjadi buku Tuntunan Menuju Keluarga Sakinah. Keberadaan fikih ini sebagai upaya mencari solusi setidaknya atas sembilan persoalan perlindungan anak dan cara mewujudkannya. Tiga persoalan berkaitan hak hidup dan tumbuh kembang anak, seperti masalah aborsi, kematian bayi dan anak balita, dan stunting. Tiga persoalan lain terkait hak sipil anak, seperti mengenai identitas anak, pengasuhan anak, dan anak berhadapan dengan hukum. Tiga persoalan lainnya berhubungan dengan hak perlindungan, yaitu pernikahan anak, pengangkatan anak, trafficking, dan kekerasan seksual terhadap anak. Semua itu dalam rangka memberikan perlindungan dan peningkatan kapasitas anak berdasarkan dalil-dalil hukum 
Islam. Tulisan ini difokuskan pada aspek hak perlindungan khususnya mengenai perkawinan anak.

Fikih perlindungan anak dibuat secara berurutan dan berjenjang terdiri dari tiga hal, yaitu nilai-nilai dasar (al-qiyam al-asayiyah) dan prinsip-prinsip umum (al-ushul al-kulliyah), dan ketentuan hukum praktis (al-ahkam al-far'iyyah). Norma dasar bersifat abstrak merupakan payung bagi norma dibawahnya, yaitu norma kedua yang memuat asas-asas umum yang merupakan deduksi dari nilai dasar. Ia merupakan konkretisasi dari nilai dasar. Sedangkan, prinsip-prinsip umum kemudian memayungi norma konkret. Pedoman praktis ini merupakan turunan dari prinsip umum. Jika prinsip umum masuk dalam dan menjadi kategori yuridis, maka ketentuan praktis ini bagian dari aspek yuridis itu sendiri. Adanya pertingkatan norma ini yang menjadi karakteristik fikih produk Muhammadiyah. Dengan karakter khas fikih Muhammadiyah maka aspek yang dibahas bukan hanya aspek amaliyah praktis (yuridis), tetapi moral-etis dan teologis. ${ }^{38}$

Penemuan solusi terhadap perkawinan anak dalam fikih perlindungan anak didasarkan pada teori dasar, teori tengah, dan pedoman praktis. Teori dasar dicari melalui penemuan terhadap nilai-nilai dasar, teori tengah digali melalui penemuan prinsip-prinsip umum, dan hak perlindungan yang diderivasi dari nilai dasar dan prinsip utama. Pertama, nilai dasar atau teori dasar dalam fikih perlindungan anak terhadap perkawinan di bawah umur adalah al-maslahah (kemaslahatan). Tujuan yang hendak dicapai oleh syariat Islam (maqashid syariah) termasuk dalam perlindungan anak adalah mewujudkan kemashlatan kemanusiaan universal (jalbu al-mashlih) dan menolak kemafsadatan (dar'u almafasid). Setiap produk Tarjih diupayakan untuk menjaga unsur-unsur maqashid syariah $^{39}$ bahkan relatif sering dipakai dalam setiap pertimbangkan dalam mengambil putusan. ${ }^{40}$ Fikih perlindungan anak merupakan sebuah ikhtiar

38 Niki Alma Febriana Fauzi, Nalar Fikih Baru Muhammadiyah: Membangun Paradigma Hukum Islam Yang Holistik, 15.1, Afkaruna, 19, 42, 2019, hlm.31

39 Samsuri and Iffah Nur Hayati, Kajian Tematis Keputusan-Keputusan Majelis Tarjih Muhammadiyah Tentang Perempuan, 5.2, Millah, 243, 260, 2006, hlm.5

40 Wawan Gunawan Abdul Wahid, Pandangan Majlis Tarjih Dan Tajdid Muhamamadiyah Tentang Nikah Sirri Dan Istbat Nikah : Analisis Maqashid Asy-Syari'ah, 12.2, Musãwa Jurnal Studi Gender Dan Islam, 215, 236, 2013, hlm.221 
mewujudkan maksud syariah pada anak. Implementasi norma konkret (al-ahkam al-far'iyyah) bagian untuk menjaga tujuan agama. Maqashid perlindungan anak dari perkawinan anak berupa nilai-nilai dasar yang salah satunya adalah almaslahah. Al-maslahah sebagai maqashid syariah bertujuan untuk mencapai maksud diturunkannya syariat oleh Allah Swt. ${ }^{41}$ Perlindungan anak dalam perkawinan di bawah umur tidak boleh didasarkan pada hawa nafsu, namun dalam rangka menolak kerusakan dan meraih manfaat. Dalam konteks perlindungan anak, setiap perilaku normatif harus diarahkan mencapai maqashid syariah yang memuat perlindungan terhadap lima pokok, yaitu perlindungan agama, jiwa, akal, keturunan, dan harta.

Kedua, prinsip umum perlindungan anak dari perkawinan anak berlandaskan pada mawaddah wa rahmah (kasih sayang) dan taufir hajiyat (pemenuhan kebutuhan hidup). Prinsip mawaddah wa rahmah merupakan konsep kasih sayang yang harus terwujud dalam membangun keluarga melalui perkawinan. Perbedaan keduanya terletak pada sumber munculnya kasih sayang. Mawaddah adalah kasih sayang yang berasal dari interaksi fisik, sedangkan rahmah berarti kasih sayang yang lahir dari interaksi hati atau batin. Jika mawaddah merupakan cinta potensial seseorang terhadap orang yang disayangi, maka rahmah adalah cinta aktual berupa usaha untuk berbuat kebaikan bagi orang yang disayangi. ${ }^{42}$ Orang tua harus memberikan kasih sayang kepada anak dengan tidak menikahkannya jika masih di bawah umur, karena dapat menghalangi terhadap pemenuhan hak anak seperti hak pendidikan, hak perlindungan eksploitasi, dan hak tumbuh kembang anak di masa mendatang.

Prinsip taufir al-hajiyat dalam perlindungan anak menempatkan kepentingan anak sebagai pertimbangan utama. Prinsip ini dikonsep supaya anak dapat memenuhi kebutuhan pokoknya sebagai bekal kehidupan di dunia dan akhirat. Orang tua harus memastikan bahwa kebutuhan anaknya terpenuhi dengan baik, sebagaimana firman Allah Swt::

\footnotetext{
41 Ika Yunia Fauzia and Abdul Kadir Riyadi, Prinsip Ekonomi Islam Perspektif Maqashid AlSyari'ah, Kencana Prenada Media Group, Jakarta, 2014, hlm.52

42 'Aisyiyah and Muhammadiyah, supra no. 25, hlm.38
} 


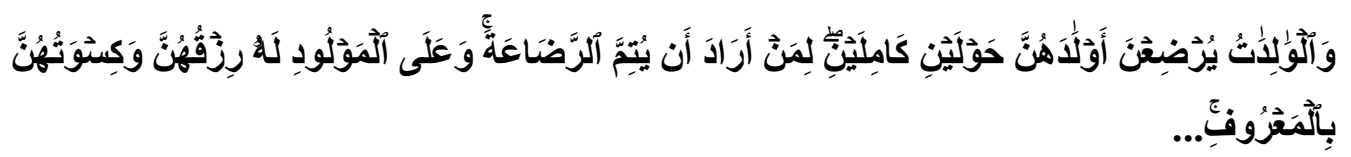

"Dan ibu-ibu hendaklah menyusui anak-anaknya selama dua tahun penuh, bagi yang ingin menyusui secara sempurna. Dan kewajiban ayah menanggung nafkah dan pakaian mereka dengan cara yang patut..." (QS. Al-Baqarah: 233).

Kebutuhan hidup anak yang didasarkan pada potensi yang dimiliki harus dipastikan terpenuhi dengan baik. Hak anak yang terancam tidak terpenuhi akibat praktik perkawinan di bawah umur adalah hak memperoleh pendidikan dan pengajaran. Hak ini sebagai wujud pengembangan potensi akal yang harus dikembangkan. Potensi intelektual anak diarahkan untuk terus berfikir dan belajar ilmu pengetahuan. Supaya anak mendapatkan hak atas pengembangan potensi dirinya, maka segala yang menghambat terwujudnya hak-hak anak harus dicegah. Dengan pengembangan kemampuan intelektual anak atas dasar keimanan menjadikan Allah Swt akan meninggikan derajat seseorang, sebagaimana firman-Nya:

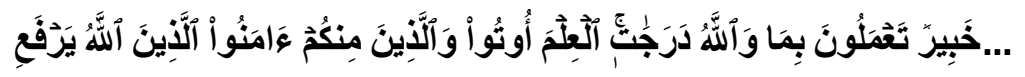
“...niscaya Allah akan meninggikan orang-orang yang beriman di antaramu dan orang-orang yang diberi ilmu pengetahuan beberapa derajat. Dan Allah Maha Mengetahui apa yang kamu kerjakan." (QS. Al-Mujadilah: 11).

Ketiga, pedoman praktis berupa hak perlindungan. Berdasarkan nilai-nilai dasar dan prinsip-prinsip umum tersebut, kemudian diimplementasikan dalam bentuk pedoman praktis dalam kerangka hak-hak anak. Sebagaimana yang dijelaskan dalam fikih perlindungan anak, maka perkawinan anak masuk ranah hak perlindungan yaitu hak dilindungi dari perkawinan anak. Meskipun semua manusia memiliki hak pernikahan, namun hak tersebut belum berlaku bagi anak jika belum sampai pada usia minimal nikah. Artinya, anak harus dihindarkan dari perkawinan di bawah umur supaya mendapatkan hak-haknya. Karena ini berkaitan dengan masa depan anak, maka segala sesuatu yang dapat meningkatkan pemenuhan hak anak harus diraih dan mencegah yang merusak. 
Hal penting yang harus dicatat dan diperhatikan adalah bahwa tidak semua persoalan anak berakhir dengan sebuah solusi berupa hukum far'iyyah yang merujuk langsung kepada Al-Qur'an dan Sunah, tetapi ada solusi berupa hukum yang tidak merujuk pada ketentuan Islam, seperti hukuman takzir terhadap tindak pidana pada anak kecil yang tidak diambil langsung dari sumber utama hukum Islam, melainkan diserahkan kepada hakim untuk memberikan hukuman setimpal sesuai yang diperbuat anak tersebut. Diperoleh juga solusi yang tidak berbentuk hukum far'iyyah, namun lebih kepada pedoman umum seperti dalam kasus perkawinan anak. Solusi yang diberikan berupa rekonstruksi pemahaman mengenai tujuan perkawinan yang berdampak terhadap keluwesan batas usia yang berbasis pada kedewasaan (rusyd) atau (asyuddah) bukan baligh. Dengan demikian, pengaturan usia pernikahan (kedewasaan) merupakan bagian penting untuk terwujudnya tujuan perkawinan sekaligus memberikan perlindungan kepada anak.

\section{Mitigasi Bencana Perkawinan Anak}

Menurut Undang-Undang Nomor 24 Tahun 2007 tentang Penanggulangan Bencana, bencana diartikan sebagai:

"Peristiwa atau rangkaian peristiwa yang mengancam dan mengganggu kehidupan dan penghidupan masyarakat yang disebabkan baik oleh faktor alam dan/atau faktor non-alam maupun faktor manusia sehingga mengakibatkan timbulnya korban jiwa manusia, kerusakan lingkungan, kerugian harta benda, dan dampak psikologis." ${ }^{43}$

Menurut penulis, perkawinan anak bagian dari bencana meskipun bukan disebabkan karena faktor alam dan non-alam, tetapi lebih pada faktor manusia dan sosial. Hal ini terbukti dari berbagai laporan dan penelitian terhadap dampak negatif akibat perkawinan anak seperti kematian ibu dan anak, pendidikan, kesehatan, stunting, psikologi, kependudukan, dan ekonomi. Jika tidak ditangani secara serius akan menjadi bencana dan memberikan efek domino bagi kehidupan mayarakat.

43 Undang-Undang R.I. No. 24 Tahun 2007, Penanggulangan Bencana, L.N.R.I. Tahun 2007 No. 66, Pasal 1 angka (1) 
Permasalahan hukum perkawinan yang menjadi masalah di masyarakat secara nasional bahkan internasional adalah perkawinan anak atau perkawinan di bawah umur. Perkawinan anak dipahami sebagai perkawinan yang dilakukan oleh pasangan laki-laki dan perempuan yang belum mencapai umur yang ditentukan oleh hukum positif pada suatu negara. Undang-Undang Perkawinan dijadikan pedoman dalam pelaksanaan perkawinan di Indonesia menyatakan laki-laki dan perempuan diizinkan menikah jika sudah berusia 19 tahun. Peraturan ini menujukkan bahwa usia perkawinan jadi bagian yang penting dan inheren dengan tujuan perkawinan, meskipun jika belum mencapai usia itu dapat mengajukan permohonan dispensasi nikah.

Undang-Undang Perkawinan tidak secara eksplisit melarang nikah di bawah umur meskipun telah diatur batas minimal usia perkawinan. Bahkan masih terdapat celah seseorang untuk melangsungkan perkawinan anak melalui dispensasi nikah yang merupakan pengecualian dari Pengadilan bagi kedua calon mempelai atau salah satu yang masih di bawah umur minimal dan boleh melangsungkan perkawinan dengan memenuhi syarat-syarat tertentu sebagaimana diatur Undang-Undang Perkawinan. Dispensasi dapat dipahami sebagai sebuah pengecualian. Dalam konteks hukum, maka hukum pengecualian merupakan tindakan berdasarkan hukum yang menyatakan bahwa suatu peraturan perundang-undangan tidak berlaku untuk suatu hal yang bersifat khusus.44 Pengaturan dispensasi nikah yang baru lebih ketat dibandingkan sebelumnya. Hal ini dibuktikan adanya ketentuan bahwa dispensasi diberikan dalam keadaan darurat dan memaksa dengan disertai bukti-bukti yang cukup serta harus mendengarkan pendapat kedua calon mempelai sebelum dilaksanakan perkawinan anak. $^{45}$

Idealnya tujuan dispensasi nikah diarahkan untuk mencapai tujuan pernikahan, yaitu terwujudnya rumah tangga yang bahagia dan kekal berdasarkan Tuhan Yang Maha Esa. Hal-hal yang lebih banyak positifnya harus menjadi

\footnotetext{
44 Mardi Candra supra no. 19, hlm. 113

45 Undang-Undang R.I. No.16 Tahun 2019, Perubahan Atas Undang-Undang Nomor 1 Tahun 1974 tentang Perkawinan, L.N.R.I. Tahun 2019 No. 186, Pasal 7
} 
pertimbangan hakim dalam pemberian dispensasi nikah dibanding hal yang negatif. Artinya, dispensasi nikah dapat diberikan atas pertimbangan meraih kemaslahatan kehidupan calon mempelai dan mencegah kemudaratan dengan harapan dapat terwujud tujuan perkawinan, meskipun syarat sah perkawinan belum terpenuhi. Hal ini supaya tidak terkesan "memudahkan" dan meremehkan hakikat perkawinan, hakim dalam memberikan penetapan dispensasi nikah harus bisa memutus seadil-adilnya dengan berpijak pada Undang-Undang Perkawinan, KHI, dan Undang-Undang Perlindungan Anak serta benar-benar mempertimbangkan maslahat mursalah (metode penemuan hukum Islam berdasarkan kemaslahatan umum). Jika selama ini hakim Pengadilan dalam memberikan dispensasi nikah masih menggunakan kriteria dewasa baligh, sudah saatnya merubah paradigmanya dengan minimal memakai pedoman rusyd.

Pemberian dispensasi harus bermuara pada pemberian perlindungan anak dan membantu calon pengantin supaya terhidar dari perbuatan yang dilarang oleh agama dan negara. Hakim harus memiliki perspektif perlindungan anak dalam menangani perkara dispensasi nikah dan berusaha mengintegrasikan UndangUndang Perkawinan dengan Undang-Undang Perlindungan Anak, sehingga terwujud perlindungan anak dalam pemberian dispensasi nikah di bawah umur. Dengan demikian, dapat dipahami bahwa tujuan pemberian dispensasi nikah bagi anak di bawah umur adalah untuk kepentingan kemaslahatan kehidupan manusia, karena dengan pemberian dispensasi diharapkan dapat membantu mewujudkan tujuan perkawinan dan mengurangi akibat yang tidak baik dalam kehidupan kedua calon pengantin.

Penyebab perkawinan anak karena faktor kemiskinan, keterbatasan pendidikan dan ekonomi, dampak negatif teknologi, konflik perang, tradisi, dan agama. Bahkan hukum terkadang bisa memberi peluang masyarakat untuk melakukan perkawinan anak. $^{46}$ Menurut Kharlie $^{47}$, ada tiga faktor utama perkawinan anak di Indonesia, yaitu karena pendidikan, ekonomi, dan hamil di

\footnotetext{
46 Koalisi Perempuan Indonesia Untuk Keadilan dan Demokrasi, et, al, Naskah Akademik RUU Perubahan UU No.1 Tahun 1974 Tentang Perkawinan, Jakarta, 2019, hlm. 14

47 Siregar and Sianturi, supra no. 5, hlm. 432
} 
luar nikah (married by accident). Pasangan yang belum dewasa namun tetap melangsungkan perkawinan akan mengalami kesulitan penyesuaian diri dalam mengemban tanggung jawab sebagai suami-istri maupun orang tua bagi anaknya yang pada akhirnya dapat menimbulkan konflik yang berkepanjangan dan perceraian. Hal ini sesuai data Badan Peradilan Agama Tahun 2014 bahwa perkawinan di bawah umur rentan mengalami perceraian dengan angka 254.951 gugat cerai, 106.608 cerai talak, dan sebanyak 11.774 anak karena hamil di luar nikah. ${ }^{48}$

Undang-Undang Perkawinan meskipun masih memberi celah adanya perkawinan anak tetapi dampak pernikahan dini mengakibatkan tidak terpenuhinya hak asasi anak. Perkawinan di bawah umur menjadikan anak kesulitan mendapatkan hak pendidikan, sehingga potensi untuk mengembangkan intelektual dan prestasi anak menjadi kurang optimal. UUD NRI 1945 Pasal 28C ayat (1) menjamin setiap orang berhak atas pendidikan dan memperoleh manfaat dari ilmu pengetahuan dan teknologi. Tetapi, praktik perkawinan di bawah umur menjadikan anak kehilangan hak pendidikan dan pengajaran yang baik. Perkawinan usia dini terlebih karena married by accident berpotensi tidak melanjutkan pendidikan. Khususnya anak perempuan yang menikah di bawah umur 18 tahun berpeluang enam kali lebih besar tidak menyelesaikan pendidikan menengah dibandingkan yang menikah di atas 18 tahun. ${ }^{49}$

Hak pendidikan yang tidak terpenuhi berdampak kepada pekerjaan. Bagi yang tidak memiliki jenjang pendidikan biasanya akan mendapatkan upah rendah karena bekerja di sektor informal, sementara sektor formal kebanyakan memberikan syarat minimal jenjang pendidikan tertentu bagi karyawannya. Perkawinan anak meskipun tidak memiliki dampak langsung terhadap partisipasi tenaga kerja perempuan, namun dengan tingginya fertilitas yang disebabkan perkawinan anak dapat mempengaruhi peran perempuan di dunia kerja dan berpengaruh pada jumlah jam kerja. Kenyataan ini dapat dimengerti karena

\footnotetext{
48 Radhiya Bustan, Persepsi Dewasa Awal Mengenai Kursus Pranikah, 3.1, Jurnal Al-Azhar Indonesia Seri Humaniora, 82, 95, 2015, hlm. 84

49

Siregar and Sianturi, supra no. 5, hlm. 432
} 
perkawinan anak akan berdampak terhadap perempuan. Apabila perkawinan perempuan dapat ditunda sampai 20 tahun diprediksi mampu menaikkan Produk Domestik Bruto (PDB). ${ }^{50}$

Orang tua yang menikahkan anaknya di usia dini dengan alasan sebagai jalan keluar dari kemiskinan merupakan bagian dari bentuk eksploitasi anak dan menjadi benih tejadinya kekerasan baik secara verbal maupun fisik dan yang menjadi korban adalah perempuan. Perkawinan pada usia anak rentan mengalami Kekerasan Dalam Rumah Tangga (KDRT) dan perceraian. ${ }^{51}$ Dampak perkawinan anak juga merambah pada aspek kesehatan dan kematian. Bayi yang lahir dari ibu berusia di bawah 20 tahun berpotensi meninggal sebelum usia 28 hari atau 1.5 kali lebih besar dibandingkan ibu berusia 20-30 tahun. Bahkan 1 dari 3 balita mengalami stunting akibat perkawinan dan kelahiran anak. Perkawinan anak di bawah 18 tahun sekitar 53 persen menderita mental disorder depresi. Ibu yang melahirkan muda rawan mengalami kerusakan pada organ reproduksi dan menjadi komplikasi saat kehamilan dan melahirkan sebagai penyebab kematian kedua terbesar untuk anak perempuan berusia 15-19 tahun. ${ }^{52}$

Perkawinan anak meskipun dalam hukum Islam (fikih) masih menimbulkan perdebatan antara kelompok tekstual dan kontekstual, dimana kelompok tekstual menyatakan setuju dengan perkawinan anak karena pemahaman agamanya yang tekstual seperti dalam memahami hadist pernikahan Rasulullah dengan Aisyah. Sementara, yang menolak perkawinan anak dalam memahami dalil hukum perkawinan disesuaikan zaman dengan menggunakan aspek kesehatan, budaya, dan psikologi. Namun, perkawinan anak dari sisi agama dianggap kurang sesuai dengan maqashid syariah nikah yaitu membangun keluarga sakinah, mawaddah dan rahmah dari suami-istri. Ibnu Syubromah secara tegas menyatakan bahwa agama melarang perkawinan di bawah umur, karena

50 Gaib Hakiki, et al, Pencegahan Perkawinan Anak : Percepatan Yang Tidak Bisa Ditunda, Badan Pusat Statistik dan Kementerian PPN/Bappenas, Jakarta, 2020, hlm. 48

51 Defi Uswatun Hasanah, Kekerasan Dan Diskriminasi Terhadap Perempuan Dalam Pandangan Hukum, 12.2, Jurnal Harkat : Media Komunikasi Gender, 109, 106, 2018, hlm. 1

52 Woro Srihastuti Sulistyaningrum, Perkawinan Anak: Dampak, Tantangan, Dan Strategi Pencegahannya, Direktur Keluarga, Perempuan, Anak, Pemuda, dan Olahraga Kementerian PPN/Bappenas, Jakarta, 2020, hlm. 8 
tidak sejalan dengan nilai esensial perkawinan dalam pemenuhan kebutuhan biologis yang menyehatkan dan mendapatkan keturunan yang berkualitas. ${ }^{53}$

Ditinjau dari konsep al-dharuriyat al-khamsah atau lima kebutuhan asasi yang harus dilindungi, perkawinan anak bertolak belakang dengan hifdz al-nafs (menjaga jiwa), hifdz al-aql (menjaga akal) dan hifdz al-nasl (menjaga keturunan). Anak di bawah umur sangat berisiko bagi jiwanya ketika melakukan hubungan seksual sementara organ reproduksinya belum matang. Akal dan pendidikan anak yang melakukan perkawinan di bawah umur kurang berkembangan maksimal, karena putus sekolah. Idealnya usia pertumbuhan dan perkembangan anak digunakan untuk peningkatan kapasitas akal. Perkawinan anak dianggap kurang makruf, karena usia anak dilihat dari segi jiwa, pikiran, dan organnya belum dewasa, sehingga belum mampu mengemban tugas sebagai orang tua bagi anakanaknya yang akan ada. ${ }^{54}$ Secara rasional, pasangan suami-istri yang telah menikah dan memenuhi persyaratan ideal baik secara fisik, mental, sosial dan ekonomi belum tentu dapat membina dan mendirikan rumah tangga secara sempurna, apalagi orang belum dewasa maka sulit menuju keluarga sakinah.

Supaya tidak menjadi bencana nasional diperlukan upaya mitigasi bencana perkawinan anak. Mitigasi bencana dapat dipahami sebagai tindakan pada tahap pra bencana yang bertujuan meminimalisir dampak yang ditimbulkan oleh bencana. ${ }^{55}$ Mitigasi ini mencakup perencaan dan pelaksanaan tindakan-tindakan untuk mengurangi risiko sebelum terjadi bencana. Mitigasi perkawinan anak di sini lebih ditekankan pada penyadaran dan peningkatan pemahaman tentang perkawinan secara holistik. Pencegahan perkawinan anak diperlukan kolaborasi dengan penyebaran informasi dan peningkatan kesadaran publik tentang urgensi pengurangan risiko pernikahan dini.

53 Achmad Suhaili, Relevansi Batas Usia Perkawinan Dalam Membentuk Keluarga Sakinah, 1.1, Al-Bayan, 1, 15, 2018, hlm. 95

54 Hasil wawancara dengan Lailatis Syarifah, Anggota Majelis Tarjih dan Tajdid Pimpinan Pusat Muhammadiyah tanggal 27 Januari 2020 jam 17.13 WIB

55 Isngadi Isngadi and Mufti Khakim, Efektivitas Undang-Undang Nomor 24 Tahun 2007 Tentang Penanggulangan Bencana Dan Fikih Kebencanaan Terhadap Perilaku Warga Muhammadiyah (Studi Kasus Covid-19), 7.1, Jurnal Komunikasi Hukum (JKH), 202, 2014, 2021, hlm. 210 
Keberhasilan melakukan mitigasi perkawinan anak dibutuhkan kesadaran bersama dengan melibatkan pihak-pihak terkait, yaitu individu, keluarga ${ }^{56}$, masyarakat, dan pemerintah. Individu yang dimaksud di sini adalah anak itu sendiri sebagai subjek atas hak-haknya. Salah satu cara meminimalkan risiko bencana adalah dengan meningkatkan kapasitas sumber daya yang ada pada setiap individu dan kemampuan lingkungan untuk mencegah bencana tersebut. ${ }^{57}$ Oleh karena itu, masing-masing calon pengantin harus memiliki literasi perkawinan yang baik mulai dari pemahaman tentang hakikat perkawinan hingga meraih keluarga sakinah. Dipastikan mempunyai bekal dan persiapan untuk membangun rumah tangga serta memahami tanggung jawab masing-masing sebagai suami-istri dan orang tua dari anaknya. Mitigasi yang demikian disebut mitigasi dari diri sendiri yang sangat diperlukan untuk mengurangi nikah dini. Orang tua (keluarga) juga punya kewajiban untuk mengarahkan supaya anak tidak terjerumus dalam perkawinan di bawah umur. Kurangnya Pendidikan Kesehatan Reproduksi dan Seksual (PKRS) yang komprehensif sejak dini juga menjadi penyebab perkawinan anak. ${ }^{58}$ Maka penting sekali menyampaikan informasi kesehatan reproduksi yang komprehensif kepada anak sesuai usia perkembangannya. Pemahaman yang baik tentang kesehatan reproduksi pada anak akan memberi manfaat bagi kesehatan dirinya dan terhindar dari perilaku negatif.

Orang tua berkewajiban mencegah terjadinya perkawinan anak demi mewujudkan anak yang berkualitas. Orang tua harus membimbing dan memastikan terpenuhinya kebutuhan anak. Hal ini sebagaimana yang ditegaskan hadist Nabi Muhammad saw.: "Ambillah dari hartanya apa yang mencukupi dirimu dan anak-anakmu dengan cara yang baik." (HR. Al-Bukhari). ${ }^{59}$ Hadist tersebut memberikan penegasan bahwa yang berkewajiban mencukupi kebutuhan hidup

\footnotetext{
56 Ade Chayawyta, et al, Pendekatan Hermeneutic Dan Teologis Studi Islam Pada Anak, 1.1, Jurnal Qurroti : Jurnal Pendidikan Islam Anak Usia Dini, 40, 62, 2019, hlm. 54

57 Suyadi, Zalik Nuryana, and Niki Alma Febriana Fauzi, The Fiqh of Disaster: The Mitigation of Covid-19 in the Perspective of Islamic Education-Neuroscience, 51, International Journal of Disaster Risk Reduction, 101848, 2020, hlm. 6

58 Kartikawati and Djamilah, supra no. 1, hlm.1

59 Abu 'Abdillah Muhammad Ibn Ismail Bukhari, supra no. 14
} 
istri dan anak adalah suami. Pemenuhan kebutuhan demi kemaslahatan anak ini berlangsung ketika masih anak-anak hingga dewasa. Lingkungan masyarakat juga berperan dan bertanggung jawab untuk berpartisipasi dalam mewujudkan lingkungan protektif dengan melakukan pencegahan perkawinan anak melalui penciptaan kehidupan masyarakat yang teratur, berpedoman pada nilai-nilai moral agama, sehingga tidak terjadi pergaulan bebas. Masyarakat dapat membantu dengan sosialisasi Undang-Undang Perkawinan dan dampak perkawinan anak. Jika ada anak yang diduga akan dinikahkan dini masyarakat harus ikut mencegah, dimediasi, dan diberi edukasi.

Sementara, pemerintah sebagai otoritas tertinggi punya tanggung jawab lebih untuk pencegahan perkawinan anak. Sebagai pengemban amanat rakyat dalam pengaturan urusan hidup yang berkaitan dengan kebutuhan hidup publik, pemerintah memiliki kewenangan dengan menggerakkan sumber daya untuk menekan angka perkawinan di bawah umur di antaranya dengan menetapkan Undang-Undang Perkawinan, Undang-Undang Perlindungan Anak, dan Peraturan Presiden Nomor 59 Tahun 2017 tentang Pelaksanaan Pencapaian Tujuan Pembangunan Berkalanjutan. Peraturan tersebut untuk mendukung penghapusan perkawinan anak di Indonesia dengan mengatur usia minimal perkawinan sebagai upaya mewujudkan keluarga sakinah. ${ }^{60}$

Mitigasi perkawinan anak menjadi bagian penting dalam pemberian perlindungan terhadap anak dan mewujudkan keluarga sakinah. Jalan menuju keluarga sakinah hanya dapat ditempuh melalui pernikahan yang dilaksanakan dengan prinsip otonomi, kedewasaan dengan mempertimbangkan usia yang matang, mitsaqan ghalizhan, kebahagiaan dan kekekalan keluarga, pernikahan yang dicatatkan, al-qiwamah, dan monogami. Dalam konteks fikih perlindungan anak, mitigasi perkawinan anak meniscayakan kerjasama antar mulai dari individu, keluarga, masyarakat, dan pemerintah dengan perannya masing-masing untuk bersama-sama memberikan edukasi kepada masyarakat agar memahami dan menyadari kemudaratan yang timbul dari perkawinan anak di bawah umur,

60 Marwa, supra no.17 
sehingga pernikahan dini dapat diminimalisir sebagai modal untuk mewujudkan Indonesia Layak Anak (IDOLA) 2030 dan Indonesia Emas 2045.

\section{Penutup}

Perkawinan anak bertentangan dengan upaya pemberian perlindungan anak dalam pemenuhan hak-hak anak seperti hak pendidikan, kesehatan, kehidupan tanpa kekerasan, dan mendapatkan hidup yang layak. Mempertimbangkan kedewasaan seseorang merupakan hal penting yang harus dilakukan calon suami-istri dalam memilih pasangan hidup sebelum menikah untuk meminimalisir perkawinan anak sekaligus usaha mewujudkan keluarga sakinah. Kriteria dewasa menurut fikih perlindungan anak bukan sekedar sudah baligh, tetapi seseorang minimal sudah mencapai rusyd atau kedewasaan secara biologis, psikologis, sosial, dan ekonomi.

Fikih perlindungan anak memberikan pedoman perlindungan kepada anak perspektif Islam. Fikih perlindungan anak berpijak pada nilai dasar al-mashlahah (kemaslahatan), prinsip umum al-mawaddah wa ar-rahmah (kasih sayang) dan attaufir al-hajiyat (pemenuhan kebutuhan), serta pedoman praktis berupa hak perlindungan supaya dilindungi (terhindar) dari perkawinan anak. Perkawinan anak kurang memenuhi unsur-unsur tujuan syariat Islam (maqashid syariah), karena bertentangan terhadap pemenuhan hifdz al-nafs (menjaga jiwa), hifdz alaql (menjaga akal) dan hifdz al-nasl (menjaga keturunan). Batas usia minimal 19 tahun untuk melangsungkan perkawinan sebagaimana Undang-Undang Perkawinan telah memenuhi kriteria fikih perlindungan anak.

Mitigasi perkawinan anak perspektif fikih perlindungan anak
mengehendaki pihak-pihak yang berkepentingan dalam memberikan
perlindungan anak agar saling kerjasama antara individu, keluarga, masyarakat,
dan pemerintah untuk bersama-sama memiliki kesadaran dan memberikan
edukasi perkawinan serta melakukan pencegahan nikah di bawah umur. Orang
tua punya andil untuk mewujudkan keluarga sakinah dengan memberikan
pendidikan Islam dan menjamin hak-hak anak dengan tidak menikahkan anaknya
di usia dini. Dalam keadaan mendesak dan darurat hakim Pengadilan dalam


memberikan penetapan dispensasi nikah harus mempertimbangkan hukum positif, kemaslahatan, dan melindungi hak-hak anak agar terpenuhi secara optimal. Hakim dalam menentukan syarat kedewasaan dapat merujuk fikih perlindungan anak dengan berpijak pada ukuran rusyd atau asyuddah bukan baligh.

\section{Daftar Pustaka}

\section{Buku:}

Abu 'Abdillah Muhammad Ibn Ismail Bukhari, Sahih Bukhari, ed. by Mustafa Dib Al-Buga, Dar Ibn Kasir dan Al-Yamamah li At-Tiba'ah wa An-Nasyr wa TaTauzi, Damaskus, 1994.

Abu Dawud Sulaiman Ibn Al- Asy's As-Sinistani, Sunan Abi Dawud, ed. by Syu'aib Al-Arna'ut dan Muhammad Kamil Qarah Balali, Mu'assasat Ar-Risalah li AtTiba'ah wa An-Nasyr wa At-Tauzi, Beirut, 1994.

Al-Imam Jalaluddin Muhammad bin Ahmad bin Muhammad Al-Mahalli, and AlImam Jalaluddin Abdirrahim bin Abu Bakar As-Suyuthi, Tafsir Jalalain, eLBA, Surabaya, 2012.

Dewan Pimpinan Republik Indonesia Rakyat, Risalah Dalam Rangka Penyusunan RUU Tentang Perubahan UU Perkawinan, Dewan Perkawilan Rakyat Republik Indonesia, Jakarta, 2019.

Gaib Hakiki, Pencegahan Perkawinan Anak: Percepatan Yang Tidak Bisa Ditunda. Badan Pusat Statistik dan Kementerian PPN/Bappenas, Jakarta, 2020.

Ika Yunia Fauzia, and Abdul Kadir Riyadi, Prinsip Ekonomi Islam Perspektif Maqashid Al-Syari'ah, Kencana Prenada Media Group, Jakarta, 2014.

Koalisi Perempuan Indonesia Untuk Keadilan dan Demokrasi, Naskah Akademik RUU Perubahan UU No.1 Tahun 1974 Tentang Perkawinan, Indonesia, 2019.

Majelis Tarjih dan Tajdid Pimpinan Pusat Muhammadiyah, Materi Musyawarah Nasional Tarjih Muhammadiyah XXX, I, Panitia Muasyawarah Nasional Tarjih Muhammadiyah XXX, Yogyakarta, 2018.

Mardi Candra, Aspek Hukum Perlindungan Anak Di Indonesia : Analisis Tentang Perkawinan Di Bawah Umur, 1st edn, Prenadamedia Group, Jakarta, 2018.

Muhammad Syafii Antonio, Muhammad SAW : The Super Leader Super Manager, IX, Tazkia Multimedia \& ProLM Center, Jakarta, 2009. 
Mukti Fajar Nur Dewata, and Yulianto Achmad, Dualisme Penelitian Hukum Normatif \& Empiris, Pustaka Pelajar, Yogyakarta, 2010.

Muslim, Shahih Muslim, ed. by Muhammad Fuad Abd Baqi, Dar Al-Fikr li At-Tiba'ah wa An-Nasyr wa At-Tauzi, Beirut, 1994.

Pimpinan Pusat 'Aisyiyah, and Majelis Tarjih dan Tajdid Pimpinan Pusat Muhammadiyah, Tuntunan Menuju Keluarga Sakinah, II, Suara Muhammadiyah, Yogyakarta, 2017.

Sonny Dewi Judiasih, at al, Perkawinan Bawah Umur Di Indonesia: Beserta Perbandingan Usia Perkawinan Dan Praktik Perkawinan Bawah Umur Di Beberapa Negara, PT. Refika Aditama, Bandung, 2018.

Woro Srihastuti Sulistyaningrum, Perkawinan Anak: Dampak, Tantangan, Dan Strategi Pencegahannya, Direktur Keluarga, Perempuan, Anak, Pemuda, dan Olahraga Kementerian PPN/Bappenas, Jakarta, 2020.

\section{Jurnal:}

Achmad Suhaili, Relevansi Batas Usia Perkawinan Dalam Membentuk Keluarga Sakinah, 1.1, Al-Bayan, 1, 15, 2018.

Ade Chayawyta, Eva Fajar Sari, Marlia Sholikhah, and Muhammad Baharuddin, Pendekatan Hermeneutic Dan Teologis Studi Islam Pada Anak, 1.1, Jurnal Qurroti : Jurnal Pendidikan Islam Anak Usia Dini, 40, 62, 2019.

Analiansyah, and Syarifah Rahmatillah, Perlindungan Terhadap Anak Yang Berhadapan Dengan Hukum (Studi Terhadap Undang-Undang Peradilan Anak Indonesia Dan Peradilan Adat Aceh), 1.1, Gender Equality: Internasional Journal Of Child And Gender Studies, 51, 68, 2015.

Aprianti, Zahroh Shaluhiyah, and Antono Suryoputro, Fenomena Pernikahan Dini Membuat Orang Tua Dan Remaja Tidak Takut Mengalami Kehamilan Tidak Diinginkan, 13.1, Jurnal Promosi Kesehatan Indonesia, 61, 73, 2018.

Defi Uswatun Hasanah, Kekerasan Dan Diskriminasi Terhadap Perempuan Dalam Pandangan Hukum, 12.2, Jurnal Harkat: Media Komunikasi Gender, 109, 116, 2018.

Fadli Andi Natsif, Problematika Perkawinan Anak: Perspektif Hukum Islam Dan Hukum Positif, 5.2, Jurnal Al-Qadau: Peradilan Dan Hukum Keluarga Islam, 175, 186, 2018.

Fransiska Novita Eleanora, and Andang Sari, Pernikahan Anak Usia Dini Ditinjau Dari Perspektif Perlindungan Anak, XIV.1, Progresif : Jurnal Hukum, 50, 63, 2020.

Inna Noor Inayati, Perkawinan Anak Di Bawah Umur Dalam Perspektif Hukum, HAM Dan Kesehatan, 1.1, Jurnal Bidan: Midwife Journal, 46, 53, 2015.

Isngadi, and Mufti Khakim, Efektivitas Undang-Undang Nomor 24 Tahun 2007 Tentang Penanggulangan Bencana Dan Fikih Kebencanaan Terhadap Perilaku Warga Muhammadiyah (Studi Kasus Covid-19), 7.1, Jurnal Komunikasi Hukum (JKH), 202, 114, 2021.

M, Ghufron, Makna Kedewasaan Dalam Perkawinan, 06.02, Al-Hukama': The Indonesia Journal of Islamic Family Law, 319, 336, 2016. 
Muhammad Fuad Zain, and Ansori , Rekontruksi Batas Usia Perkawinan Pasca Putusan MK No. 22/PUU-Xv/2017 Sebagai Penguat Bangsa Di Era Industri 4.0, 1.1, ADHKI: Journal of Islamic Family Law, 45, 56, 2019.

Muhammad Habibi Miftakhul Marwa, Pengaturan Batas Usia Perkawinan Perspektif Keluarga Sakinah Muhammadiyah, 7.1, Justisi, 1, 13, 2021.

Niki Alma Febriana Fauzi, Nalar Fikih Baru Muhammadiyah: Membangun Paradigma Hukum Islam Yang Holistik, 15.1, Afkaruna, 19, 42, 2019.

Nur Fadhilah Khairiyati Rahmah, Rekontruksi Batas Usia Perkawinan Anak Dalam Hukum Nasional Indonesia, 4.1, Journal de Jure, 49, 61, 2012.

Radhiya Bustan, Persepsi Dewasa Awal Mengenai Kursus Pranikah, 3.1, Jurnal AlAzhar Indonesia Seri Humaniora, 82, 95, 2015.

Reni Kartikawati, and Djamilah, Dampak Perkawinan Anak Di Indonesia, 3.1, Jurnal Studi Pemuda, 1, 16, 2014).

Samsuri, and Iffah Nur Hayati, Kajian Tematis Keputusan-Keputusan Majelis Tarjih Muhammadiyah Tentang Perempuan, 5.2, Millah, 243, 260, 2006.

Sofia Hardani, Analisis Tentang Batas Umur Untuk Melangsungkan Perkawinan Menurut Perundang-Undangan Di Indonesia, 40.2, An-Nida': Jurnal Pemikiran Islam, 126, 339, 2015.

Supri Yadin Hasibuan, Pembaharuan Hukum Perkawinan Tentang Batas Minimal Usia Pernikahan Dan Konsekuensinya, 1.2, Teraju: Jurnal Syariah Dan Hukum, 79, 87, 2019.

Suyadi, Zalik Nuryana, and Niki Alma Febriana Fauzi, The Fiqh of Disaster: The Mitigation of Covid-19 in the Perspective of Islamic Education-Neuroscience, 51, International Journal of Disaster Risk Reduction, 101848, 2020.

Thogu Ahmad Siregar, and Petrus Richard Sianturi, Dispensasi Kawin Akibat Hamil Di Luar Perkawinan Dan Dampaknya Pada Formulasi Pidana Zina, 6.2, Veritas et Justitia, 424, 449, 2020.

Wawan Gunawan Abdul Wahid, Pandangan Majlis Tarjih Dan Tajdid Muhamamadiyah Tentang Nikah Sirri Dan Istbat Nikah : Analisis Maqashid Asy-Syari'ah, 12.2, Musãwa Jurnal Studi Gender Dan Islam, 215, 236, 2013.

Internet:

Badan Kependudukan dan Keluarga Berencana (BKKBN) https://www.bkkbn.go.id/detailpost/perkawinan-usia-anak-bencananasional-yang-gerogoti-ekonomi-indonesia, diakses 30 April 2021, jam 10.14 WIB.

\section{Undang-Undang:}

Undang-Undang Dasar Negara Republik Indonesia Tahun 1945

Undang-Undang R.I. No. 39 Tahun 1999, Hak Asasi Manusia, L.N.R.I. Tahun 1999 No. 165

Undang-Undang R.I. No. 23 Tahun 2002, Perlindungan Anak, L.N.R.I. Tahun 2002 No. 109

Undang-Undang R.I. No. 24 Tahun 2007, Penanggulangan Bencana, L.N.R.I. Tahun 2007 No. 66 
Undang-Undang R.I. No. 35 Tahun 2014, Perubahan Atas Undang-Undang Nomor 23 Tahun 2002 tentang Perlindungan Anak, L.N.R.I. Tahun 2014 No. 297

Undang-Undang R.I. No. 1 Tahun 1974, Perkawinan, L.N.R.I. Tahun 1974 No. 1

Undang-Undang R.I. No.16 Tahun 2019, Perubahan Atas Undang-Undang Nomor 1 Tahun 1974 tentang Perkawinan, L.N.R.I. Tahun 2019 No. 186

\section{Wawancara:}

Wawancara dengan Hamim Ilyas, Wakil Ketua Majelis Tarjih dan Tajdid Pimpinan Pusat Muhammadiyah, tanggal 26 Juni 2020 jam 14.08 WIB

Wawancara dengan Lailatis Syarifah, Anggota Majelis Tarjih dan Tajdid Pimpinan Pusat Muhammadiyah tanggal 27 Januari 2020 jam 17.13 WIB

Wawancara dengan Wawan Gunawan Abdul Wahid, Anggota Majelis Tarjih dan Tajdid Pimpinan Pusat Muhammadiyah tanggal 24 Januari 2020 jam 18.12 WIB 